\title{
Effect of Precipitation Change on Dams Storage in Jordan
}

\author{
Mjed ali alsaraireh
}

\begin{abstract}
Precipitation patterns' change, rising surface temperature, extensive ice melting and increments in intensity and frequency of droughts and floods are several kinds of the reported hydrologic changes that are connected with the worldwide climate change. Therefore, climate change and its associated precipitation change are anticipated to influence the water storage as well as water supply in Jordan and impose challenges in front of the current water management policies and plans. The hydrological impacts of upcoming anticipated climate may influence the Jordanian dams' capacity and operating attributes. Accordingly, this paper tends to explore and review mainly the effect of precipitation change on dams' storage in Jordan, by providing a brief review of major types of dams and considerations that must be taken through their design and construction as well as clarifying the necessity for a national climate change policy for Jordan. The researcher concluded that climate change and precipitation variability require new management strategies for water storage infrastructures (reservoirs), including the design for new dams and rehabilitation of the infrastructure of aging dams as well as imposing new operational systems. Several advantages of dam management ought to be considered, evaluated and actualized right away in Jordan alongside with issuing of national climate change policy taking into account the effect of precipitation change.
\end{abstract}

DOI: $10.7176 / \mathrm{JEES} / 9-5-05$

Publication date:May $31^{\text {st }} 2019$

\section{Introduction}

In the recent four decades, water quality as well as its availability have become of a high significant concern in Jordan. The accessible water from the current sustainable assets are anticipated by the year 2025 , to fall beneath $91 \mathrm{~m} 3 / \mathrm{c} . d$. This is a very low proportion compared with the worldwide, $1000 \mathrm{~m} 3 / \mathrm{c} . \mathrm{d}$, water poverty line (Al Smadi, Al-Zboon, \& Al-Azab, 2010). Water deficiency has enforced Jordan to take care of all accessible water assets in order to overcome any issues among available water supply and demand (Al-Tabbal and Al-Zboon 2012).

In countries such as Jordan, where the severe drought season has an expected impact on climate change and where the access to fresh water rely heavily on upstream countries, the effect of drier conditions and subsequent changes in transboundary water flow have prompted Jordan to address water scarcity more than other problems related to climate variability such as change in precipitation and its effect on dams storage which may lead to floods in some cases (Rajsekhar \& Gorelick, 2017).

However, in previous studies such as Freiwan and Kadioglu (2008) where an arithmetical rationalizing model was utilized to create site-scale climate future scenarios for the upcoming period of 2011-2099, at different Jordanian sites from the coarse GCM products, the study show that extreme events including, extreme rainfall, flash floods and rapid snow storms, are anticipated to be more frequent requiring Jordan to pay attention to the problems of absorptive capacity and designed storage of reservoirs and the possibility of flooding in a manner similar to that of water scarcity problems (Jordanian Ministry of Environment, 2013).

Accordingly, it is clear that climate change is altering hydrological cycles implying that historical climate data may not be a reliable indicator of future hydrological patterns in Jordan, which leads to the need of reinvestigating reservoirs, including dams that are designed to suit their climate at the time, and are ill-prepared for rapid shifts in river flows and precipitation increment. This study will therefore attempt to explore the effect of climate change, especially precipitation change, on the storage of Jordanian dams.

\section{Problem Statement and Study Objectives}

Long term climate change has been seen at regional and continental scales, because of the increment in greenhouse's concentration especially carbon dioxide. These incorporate changes in precipitation amounts and intensity, temperatures, and other extraordinary climate like substantial precipitation, floods, drought and heat or wind waves (IPCC, 2007).

Climate change will influence water assets' demand and supply, affecting freshwater biological systems and environment administrations around the world (Palmer et al. 2008). Several models foresee progressively extreme events including, overflowing and dry season (Bates et al. 2008). The water obtainability and its annual average runoff are anticipated to rise at great values by the mid- $21^{\text {st }}$ century, due to the expected increments in the intensity as well as the frequency of extreme climate events (Kundzewicz et al. 2008). This anticipated increment in water runoff and precipitation intensity may in turn affect the patterns of stream flow altering the operations of it and imposing effects on the existing water infrastructures and reservoirs and may result in 
overflowing events that may surpass the design limits of some dams (Najibi \& Devineni, 2018).

Present water management might not sufficiently deal with with the previously mentioned effects of climate change on water supply's reliability, flood hazard and the adequacy of constructed water management systems and reservoirs. The hydrological effects of future climate change will probably need essential changes to existing water management strategies and plans, with prominent adjustment of dam operations (Watts et al., 2011). Nonetheless, while considerable work has recorded the possible effects of climate change on many water storing facilities or even with regards to dams in various countries all around the world (Kang et al., 2007; Kim et al., 2009; Lauri et al., 2012), the effect of climate change particularly precipitation change on dams storage have not been well documented and investigated in a country where water management represents a vital issue for it, which is Jordan.

Therefore, this paper tends to explore and review mainly " The effect of precipitation change on dams storage in Jordan", which would be achieved through the following sub-objectives:

1) To identify the climate and precipitation change and its impact on Jordan.

2) To review major types of dams and considerations that must be taken through their design and construction.

3) To clarify the need for a national climate change policy for Jordan

\section{Methodology}

This environmental and water management study is based on descriptive methodology, in which the researcher reviews previous studies, papers, articles and literature related to the current subject in order to achieve the objectives of the study.

\section{Climate and Precipitation Change}

Climate changes in both temperature as well as precipitation in many developing nations did not get enough concern locally and globally despite the fact that these nations suffer real ecological and water assets issues. Jordan represents a country of the ten most recognized nations with the least dimensions of water assets and encounters several problems in managing water resources and utilization (Smadi \& Zghoul, 2006).

The pattern of precipitation isn't distributed equally over the world and is governed by moisture availability and atmospheric circulation patterns. These two elements are affected by temperature so the pattern of precipitation is expected to change related to any change in temperature. The changes incorporate the type of precipitation, the frequency, the amount and the intensity. Precipitation pattern has been changed in several countries regarding its intensity, amount and timing leading to mismanagement of several water storages including dams and surface reservoirs (Trenberth et al., 2007).

Expanding worldwide average air and sea temperature can change the kind of precipitation through the winter season (IPCC, 2007). The pattern of precipitation is changing from snow to rain in Northern areas and hilly zone so that heavy precipitation events have expanded even in spots where rain amounts total have diminished (Barnett et al., 2008). All of these alterations are related with expanding worldwide temperature since warmer air can hold and convey more water vapour (Santer et al., 2008).

Precipitation in Jordan is the main guaranteed sustainable water source. Several investigations on precipitation have been conducted in Jordan and its region. These examinations concentrated on precipitation pattern valuation as well as time series investigation for short record lengths of total precipitation data got from different stations. Precipitation and climates' studies in Jordan such as, Freiwan \& Kadioglu, 2008 and Smadi \& Zghoul, 2006, indicated that extreme fluctuation in precipitation leading to extreme events are expected to be more recurrent in Jordan. Smadi and Zghoul (2006) indicated that a higher rainfall's reliability was perceived in the sub-period after the change point and the variability's source might be the incidence of rare events, in which four statistical outliers have been identified afterward 1957.

Hence, it was recommended through their study to improve conventional water management practices in Jordan which mainly depend on stationarity and past hydrological experience that didn't take future predictions into consideration. This may lead to underestimation of precipitation's amount and intensity of future rainy storms leading to over flooding of some reservoirs' facilities including dams (Smadi \& Zghoul, 2006).

This shows that climate and precipitation change in Jordan poses risks especially if water management and storage systems including the dams were designed based on historic records without consideration of the future climate projections (Smadi \& Zghoul, 2006). The underestimated or overestimated design of dams may result into having a dam that operates into a different point from the potential of its capacity. Therefore, a new mechanism has to be put in place to cope with the lower or higher water levels.

Dams and Considerations that must be taken through their Design and Construction

The dam is an engineering building (reservoir) that is constructed with the purpose of reserving water. They are one of the oldest known water installations to humanity. It is a hydraulic structure of somewhat impermeable 
materials constructed through the river to produce a reservoir on the upstream side to reserve water for different purposes. Dams are typically categorized regarding to their building materials, their forms as well as their construction's purposes. The most known kinds of dams are those that constructed from one type of material or from rock drilling and concrete facade, as well as the gravity concrete dams, arc ones or butters (Guidelines for the operation and maintenance of dams in Texas, 2002).

Dams are composed from several parts, that have different functions and aid this reservoir in its storing operation, including crest, parapet walls, heel, toe, abutments, gallery, sluice way and spillway which represents a focal dams' part responsible for managing the surplus amount of water by escaping it through a passage located at the top of the dam resulting into saving the structure from failure due to the water overloading that exceeds the dam's capacity (Guidelines for Operation and Maintenance of Dams in Texas, 2002).

The dam construction process is a long-lasting methodology to diminish the spatiotemporal fluctuation of regular water supply. By controlling the water flow, dams change the normal hydrograph to provide a reliable source of water that can satisfy a wide range of natural and human needs. However, those dams are affected significantly by climate change and droughts and floods are among the most important natural hazards that might affect dams' operations negatively (Baker et al., 2011).

Hence, with climate and precipitation change, strategies for re-operating dams should take in consideration the expanded risk of floods as well as droughts and implications of hydrological inconsistency and energy supply while looking for the enhancing of the gained profits for biological systems and society (Richter \& Thomas 2007).

Such strategies should incorporate the floodplain management which might develop the dam operation and its storage, expanding flexibility to changing hydrological designs. If re-connecting the floodplains makes the downstream capacity additional for the storage and transport of floodwater, administrators of dam can reduce the amount of water retained in the dam for flood control and benefit from nature and water users. Reducing flood reservations (allowing the dam to rise above the normal flood control level) would allow more water to be stored in the dam than in the previous situation. This additional water can be used to generate water for users in dry years as well as re-creating flood pulses in wet years and enlarging the hydropower income (Watts et al., 2011).

Such a strategy was conducted by Jordanian government recently, where the King Talal Dam in Jerash overflowed for the first time since its construction over four decades ago, due to unprecedented intense precipitation, leading the government to open its floodgates in order to release the excess water and mitigate flooding event (Namrouqa, 2019).

Therefore, dam reoperation and storage management requires great data, coordinated effort and finance. Judgements should be founded on systematic proof, including: evaluations of the key components of flow to be re-established downstream of a dam; possible water savings or losses; cooperative energies among floodplain management; dam flood control and knowledge of risks and trade-offs (Allan et al. 2009).

\section{National Climate Change Policy for Jordan}

Jordan perceives that climate and precipitation change is a genuine and pervasive risk to humanity and natural resources. However, no national climate change policy has been implemented in Jordan although of the several climate changes' consequences faced by Jordan till now. This policy is presently required for the following reasons as mentioned by the Jordanian Ministry of Environment (2013):

- Formulate generally climate change destinations for Jordan ;

- Offer direction from climate perspectives to sector strategies;

- $\quad$ Mitigating extreme climate events including floods and droughts;

- Reoperation and managing water reservoirs and supply systems efficiently and safely;

- And prioritize policies, rules and tools for basic approaches and measures to manage and confront climate change.

This Policy will offer a guiding support for the Jordanian government to implement the key national climate change objects related to climate change mitigation and confronting of extreme climate and precipitation events through a high quality management of water storage systems including dams (Jordanian Ministry of Environment, 2013).

\section{Conclusions}

Climate change and precipitation vulnerability will require new management strategies for water storage infrastructures (reservoirs), including the design for new dams and rehabilitation of aging ones as well as improving their existed or expected design operation. Increment in runoff can change estimates of the dams' maximum capacity and storages, leading dam operators to make several improvements and adjustments to the dam in order to make it agreeable with the anticipated capacity and operating in a safe manner. Dam reoperation and storage management is a climate change adjustment measure, with advantages for the humanity and environment. Even with negligible small change in precipitation and overflow, the modification of dams' 
operations would exploit its benefits for ecosystems and society. Several advantages of dam management ought to be considered, evaluated and actualized right away in Jordan alongside with issuing of national climate change policy taking into account the effect of precipitation change.

\section{References}

1) Al Smadi, B., Al-Zboon, K., \& Al-Azab, T. (2010). Water management and reuse opportunities in a thermal power plant in Jordan. African Journal of Biotechnology, 9(29), 4606-4614.

2) Allan, C., Watts, R. J., Commens, S., \& Ryder, D. S. (2009). Using adaptive management to meet multiple goals for flows along the Mitta Mitta River in south-eastern Australia. In Adaptive Environmental Management (pp. 59-71). Springer, Dordrecht.

3) Al-Tabbal, J. A., \& Al-Zboon, K. K. (2012). Suitability assessment of groundwater for irrigation and drinking purpose in the northern region of Jordan. Journal of Environmental Science and Technology, 5(5), 274-290.

4) Baker, D. W., Bledsoe, B. P., Albano, C. M., \& Poff, N. L. (2011). Downstream effects of diversion dams on sediment and hydraulic conditions of Rocky Mountain streams. River research and applications, 27(3), 388-401.

5) Barnett, T. P., Pierce, D. W., Hidalgo, H. G., Bonfils, C., Santer, B. D., Das, T., ... \& Cayan, D. R. (2008). Human-induced changes in the hydrology of the western United States. science, 319(5866), 1080-1083.

6) Bates, B. C., Kundzewicz, Z. W., Wu, S., and Palutikof, J. P. (Eds) (2008). Climate change and water. Technical Paper of the Intergovernmental Panel on Climate Change, IPCC Secretariat, Geneva.

7) Freiwan, M., \& Kadioglu, M. (2008). Spatial and temporal analysis of climatological data in Jordan. International Journal of Climatology, 28(4), 521-535.

8) Guidelines for Operation and Maintenance of Dams in Texas (2002). Texas Commission on Environmental Quality. Retrieved from: https://www.tceq.texas.gov/publications/gi/gi_357

9) IPPC, Climate Change 2007: A report of Working Group I of the Intergovernmental Panel on Climate Change, Summary for Policymakers. Retreived from: http:/www.ipcc.ch/pdf/assessmentreport/ar4/wg1/ar4-wg1-spm.pdf.

10) Jordanian Ministry of Environment (2013). The National Climate Change Policy of the Hashemite Kingdom of Jordan 2013-2020. Retrieved from: http://www.moenv.gov.jo/AR/PDFs/Climate\%20change\%20policy_PDF.pdf

11) Kang, B., Lee, S. J., Kang, D. H., \& Kim, Y. O. (2007). A flood risk projection for Yongdam dam against future climate change. Journal of Hydro-environment Research, 1(2), 118-125.

12) Kim, S., Tachikawa, Y., Nakakita, E., \& Takara, K. (2009). Reconsideration of reservoir operations under climate change: case study with Yagisawa Dam, Japan. Annual Journal of Hydraulic Engineering, JSCE, 53, 597-611.

13) Kundzewicz, Z. W., Mata, L. J., Arnell, N. W., Döll, P., Jimenez, B., Miller, K., ... \& Shiklomanov, I. (2008). The implications of projected climate change for freshwater resources and their management. Hydrological sciences journal, 53(1), 3-10.

14) Lauri, H., Moel, H. D., Ward, P. J., Räsänen, T. A., Keskinen, M., \& Kummu, M. S. (2012). Future changes in Mekong River hydrology: impact of climate change and reservoir operation on discharge. Hydrol. Earth Syst. Sci. 16, 4603-4619. doi:10.5194/hess-16-4603-2012.

15) Najibi, N., \& Devineni, N. (2018). Recent trends in the frequency and duration of global floods. Earth System Dynamics, 9(2), 757-783.

16) Namrouqa, H. (2019). King Talal Dam overflows for third time this month. The Jordan Times, Retrieved from: http://www.jordantimes.com/news/local/king-talal-dam-overflows-third-time-month

17) Palmer, M. A., Reidy Liermann, C. A., Nilsson, C., Flörke, M., Alcamo, J., Lake, P. S., \& Bond, N. (2008). Climate change and the world's river basins: anticipating management options. Frontiers in Ecology and the Environment, 6(2), 81-89.

18) Rajsekhar, D., \& Gorelick, S. M. (2017). Increasing drought in Jordan: Climate change and cascading Syrian land-use impacts on reducing transboundary flow. Science advances, 3(8), e1700581.

19) Richter, B., \& Thomas, G. (2007). Restoring environmental flows by modifying dam operations. Ecology and society, 12(1).

20) Santer, B. D., Thorne, P. W., Haimberger, L., Taylor, K. E., Wigley, T. M. L., Lanzante, J. R., ... \& Karl, T. R. (2008). Consistency of modelled and observed temperature trends in the tropical troposphere. International Journal of Climatology, 28(13), 1703-1722.

21) Smadi, M. M., \& Zghoul, A. (2006). A sudden change in rainfall characteristics in Amman, Jordan during the mid 1950s. American Journal of Environmental Sciences, 2(3), 84-91.

22) Trenberth, K. E., \& Shea, D. J. (2006). Atlantic hurricanes and natural variability in 2005. Geophysical Research Letters, 33(12). 
23) Watts, R. J., Richter, B. D., Opperman, J. J., \& Bowmer, K. H. (2011). Dam reoperation in an era of climate change. Marine and Freshwater Research, 62(3), 321-327. 